\title{
Sing Your City: Local Stories of Global Artifacts*
}

\author{
Alexander Rosenblatt \\ Zefat Academic College, Zefat, Israel
}

\begin{abstract}
The article discusses five local stories that, without being connected to each other, tell about the socio-cultural circumstances accompanying creation of works of art that have received significant (but not the highest) recognition on a global scale. The discussion concerns three songs about cities: Torna a Surriento, Moscow Nights, and Li Beirut; a famous Soviet painting Low Marks Again; and the design features of Audi cars for the US market over the past decade. The approach to each certain artifact, be it song, painting, or the design of rear turn signals, is developed on the basis of disciplinary affiliation, whereas a discipline is more sociology, anthropology, or history of an appropriate art, than its theory. Another research method places a local context into the test tube of globalization. Experience shows that these two methods are applicable to different arts, places, and periods enriching the scientist with more detailed information about the era studied.
\end{abstract}

Keywords: global artifact, second echelon, songs about cities, dog in a painting, rear turn signals

\section{Introduction}

Life in a global era dictates its own laws. One of those is undoubtedly the increasing level of standardization of life, especially in cities, and even more so in megacities. Houses, apartments, cars, food, and work - all this is almost unified. Nature and weather seem to strongly resist standardization, although the microclimate in residential, industrial, and commercial premises, as well in cars, is practically equalizing this part of the differences in the lives of people at different continents and latitudes. So what remains to be different - culture, art, or music? It would seem that aesthetic criteria in relation to art and music are so national that there is no place for unification. But even here globalization has its own patents: Folk music (folklore) increasingly follows the global pattern of "world music", using the strength of Western technology and the unified platform of the Western tonality, and thus gradually moving away from its original audience. National/ethnic art is being replaced by standard samples of the "world classics", including the era of modernism and postmodernism, as well as pop art (both in the visual arts and in music) ${ }^{1}$.

Globally hyped brands are among the standard samples of the world classics: Mozart in music, Rolls-Royce in premium class cars, Leonardo in Renaissance painting, and Duchamp and Pollock in modern art. We do not even ask why everyday accessories made in an ordinary factory are considered works of art if signed by an hyped artist or why a painting by an artist struggling to make ends meet at the end of the 19th century

\footnotetext{
* Acknowledgement: The author would like to thank Prof. Joseph Bonnici of Central Connecticut State University who has supported his approach to local and global subjects and encouraged him to present on topical issues of the day as part of the introductory and keynote addresses on 2012, 2014, and 2018 conferences of the International Journal of Arts and Sciences on the Harvard Campus.

Alexander Rosenblatt, Ph.D., lecturer, Department of Literature, Art, and Music, Zefat Academic College, Zefat, Israel.

1 In recent decades, various aspects of these and related issues became part of interdisciplinary discourse and have been discussed from different viewpoints (Appadurai, 1996; Loomba, 1998; Stokes, 2004; Regev \& Seroussi, 2004).
} 
gains many millions in value at the beginning of the 21 st, not being much different from the pictures of dozens of other artists of this style.

Of the works of art that deserve global recognition, only a tiny part is promoted or simply accessible to the world community. Others are much less represented on the Internet and studied. However, it is these global artifacts of the "second echelon" that are often of the greatest interest for studying the context of the era and, moreover, can help eliminate inconsistencies relating to the study of artifacts of the top echelon and even sometimes challenge ridiculous assessments of art critics (Brauer, 2013, pp. 92-94; Konečni, 1984, pp. 90-91).

A fine example of the art collection of this very kind is the Seattle Museum of Art (Seattle, WA), which with generous support of the native of this city, William Henry Gates III (commonly known as Bill Gates), through the Bill \& Melinda Gates Foundation, and of other donors, the first-class works by the artists who did not gain world-famous status make up an exhibition that can compete with a museum collection of big names, along with the rich collection of the folk art of the North-West Pacific which presents not less interest and value.

This article, which discusses five global artifacts that can also be attributed to the above group, is aimed at developing a methodology suitable for working with artifacts in various art forms. The approach to each specific artifact will be based on the tools of disciplinary research, whereas a discipline will be more sociology-based or anthropology-based study of a correspondent art, than the theoretical aspects of its study. The objects in question will be three songs about cities, a painting with a dog, and the design of the rear turn signals on Audi cars for the North American market.

\section{Rebirth of an Italian Song}

Ask inhabitants of New York, Paris, or Moscow how many songs are written about their cities-hardly anyone will answer, even approximately. But every inhabitant of Sorrento (Province of Naples, Italy) will answer this question: One, but which one!

Most sources associate the appearance of the song Torna a Surriento (Come back to Sorrento) with the visit of Italian Prime Minister Giuseppe Zanardelli to Sorrento in 1902. According to legend, the mayor of the city tried to use the opportunity to secure the opening of the post office in this small town but was refused. Then, a friend of the mayor, Giambattista De Curtis, professional artist and amateur poet, came to the aid: "Do not worry: I will write a song for your guest!”.

The text was immediately written, and Giambattista turned to his brother Ernesto De Curtis with a request to find a suitable melody. The music was then composed, and that evening amateur musicians learned the song.

When the Prime Minister went to the station the next day, he was accompanied by this song performed by local musicians:

$\begin{array}{ll}\text { Vide 'o mare quant'è bello, } & \text { Hear the music of the waters, } \\ \text { spira tantu sentimento, } & \text { Vows of tender passion sighing, } \\ \text { Comme tu a chi tieni mente, } & \text { Like thy heart to which go flying } \\ \text { Ca scetato 'o fai sunnà. } & \text { All my thoughts in wakeful dream. }{ }^{2}\end{array}$

The important guest apparently liked the song, as soon there was its own post office in Sorrento (Volkov, 1967, p. 12). Yet, according to family documents, the melody was composed much earlier, and Giambattista only wrote a new text on the occasion of the arrival of the Prime Minister. After some changes in the text, the

\footnotetext{
${ }^{2}$ English lyrics adapted by Claude Aveling.
} 
song was performed by mezzo-soprano Maria Cappiello at the music festival in Piedigrotta, a suburb of Naples in 1905 , after which the popularity of the song increased dramatically. In the same year, the notes of the song were released by Bideri, Naples ${ }^{3}$.

Torna a Surriento, becoming one of the most famous Neapolitan songs ${ }^{4}$, gained popularity in many countries and was translated into many languages. A version of this song, arranged in 1960 by Elvis Presley, can be rather considered a separate song, since changes occurred not only in the song's title-Surrender - and its lyrics, but also in a metric basis: The triple meter gave way to the quadruple one, which considerably changed the song:

When we kiss my heart's on fire

Burning with a strange desire

And I know, each time I kiss you

That your heart's on fire too

Elvis, who belongs to another generation of songwriters, has adapted two Italian songs to suit his style, sense of time, and expectations of his audience. Surrender, along with It's Now or Never (originally O sole mio), remained Neapolitan songs that were "reborn" in the 1960s, becoming American songs by the leading rock and roll singer and songwriter.

Elvis's Surrender hit number one in the US and UK in $1961^{5}$ and eventually became one of the best-selling singles of all time.

\section{A Dog That Does not Care}

The picture (see Figure 1) is one of the most famous works of Soviet art: Everyone who grew up in the former Soviet Union had to write an essay on this topic at a certain stage, since it was in the curriculum of the Soviet school. What makes this picture so special, what message (or messages) does it convey to the viewer or, more precisely, to the attentive reader?

The painting, made in the genre of everyday life, in a completely realistic style, contains so many signs, symbols of the epoch, texts, and subtexts that to some extent it can be considered the Encyclopedia of the Soviet life of the 1950s. History of its creating, its place among the other works of the artist and its iconic status in the curriculum of the Soviet school—all this cannot but arouse curiosity among an inquisitive anthropologist of art.

Little is known about the artist. Tatyana Zelyukina, curator of the State Tretyakov Gallery in Moscow (where the painting is located) collects biographical details bit by bit. Fyodor Reshetnikov, who was born in the family of an icon painter, became an orphan at the age of three. He was raised in the family of an older brother, one of his father's 13 children. At the call of the Komsomol, he went on two polar expeditions as an artist. Brilliantly mastered the genre of caricature... ${ }^{6}$

\footnotetext{
3 According to “'Torna a Surriento' all' inaugurazione della mostra su Giuseppe Zanardelliil 16 ottobre”, published on October 9, 2010 at Circolo Culturale Ghislandi. http://www.circologhislandi.net/avvisi/torna-a-surriento-allinaugurazione-della-mostrasu-giuseppe-zanardelli-il-16-ottobre.

4 That is, the songs of the Province of Naples.

5 See Official Singles Chart Top 50, June 1-7, 1961, https://www.officialcharts.com/charts/singles-chart/19610601/7501.

6 "Fyodor Reshetnikov's Painting "Low Marks Again"” (in Russian). Radio Echo of Moscow (Series: "Collection of the Tretyakov Gallery"), retrieved May 27, 2019 from https://echo.msk.ru/programs/tretiakovka/45754/.
} 


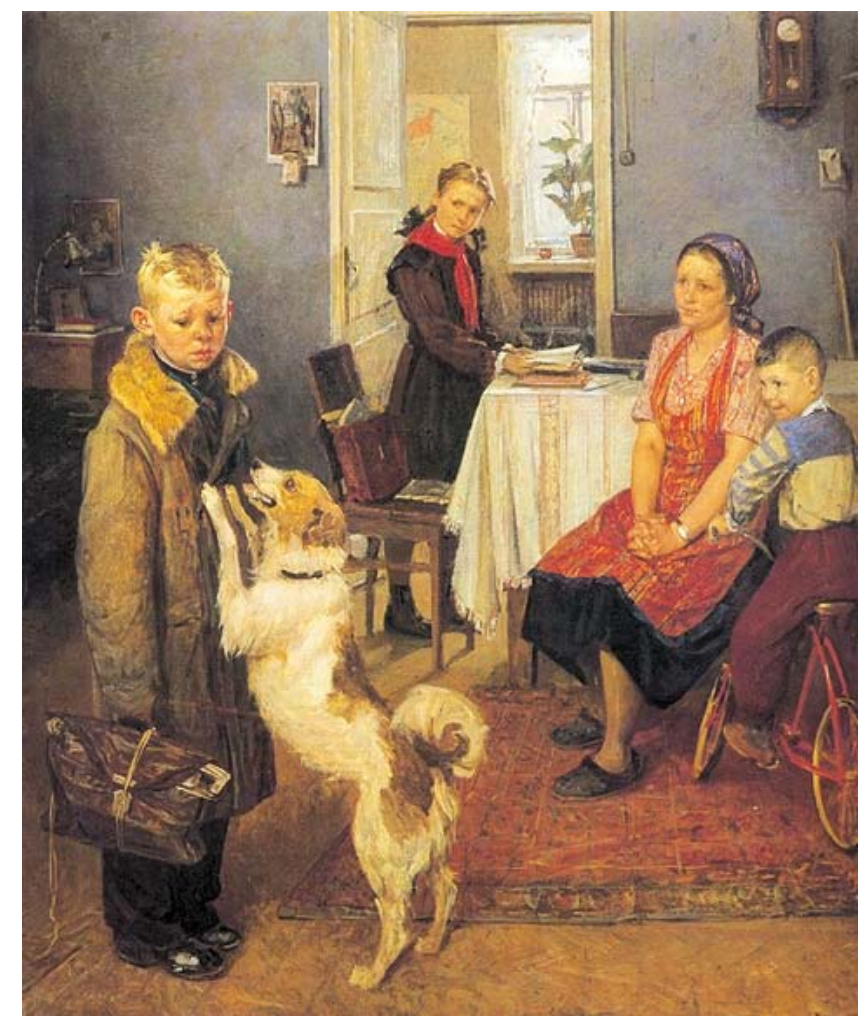

Figure 1. Fyodor Reshetnikov, Low Marks Again, 1952.

Low Marks Again is the second part of the artist's trilogy: The first part is Arrived on Vacation; the third part is Re-examination. It is noteworthy that in the left corner of the Low Marks Again, a reproduction of Arrived on Vacation is visible, while in the left corner of the Re-examination, there is a reproduction of the Low Marks Again.

The plot of the picture has undergone several changes in the process of the artist's work on it. According to the artist, the original idea of the work was completely different: The picture was called "High Marks Again" and reflected the everyday life of the future builders of the new socialist society, where the losers had no place. Developing the content of the future picture, the artist attended schools, and the plot change was influenced by the case when an excellent student, whom he chose as his model, could not complete the task and received a low mark. Now, the artist decided to portray the "loser" - a very bold innovative solution for those times, in some ways even humanistic, moving away from the main line of the Communist party, but not too much, not for a long distance: to make the hero of the work not an excellent student, but a $\operatorname{loser}^{7}$. Soon the picture was ready: It showed an unsuccessful student, over whom a formidable but fair teacher hung (see Figure 2).

But suddenly everything changed dramatically again. It was at this very time, when a new canvas had already appeared, the artist's daughter came home from school - the unhappy one had arrived and received a low mark. The artist took advantage of the inspiration that arose on this occasion, and decided to redo the picture: Bad student needs to be shown in his family ${ }^{8}$, when the only family member with a kind heart and living soul is a dog who, feeling a human misfortune, hurries to calm him down with her sincere dog caresses.

\footnotetext{
7 “Наш любимый «двоечник»” (Our favorite “loser”), Днепр вечерний, July 28, 2010, p. 8.

${ }^{8}$ Ibid.
} 
"It was this warmth that aroused interest in this picture", Zelyukina says, "when it represented Soviet art in Brussels in 1958 among many other works" $"$.

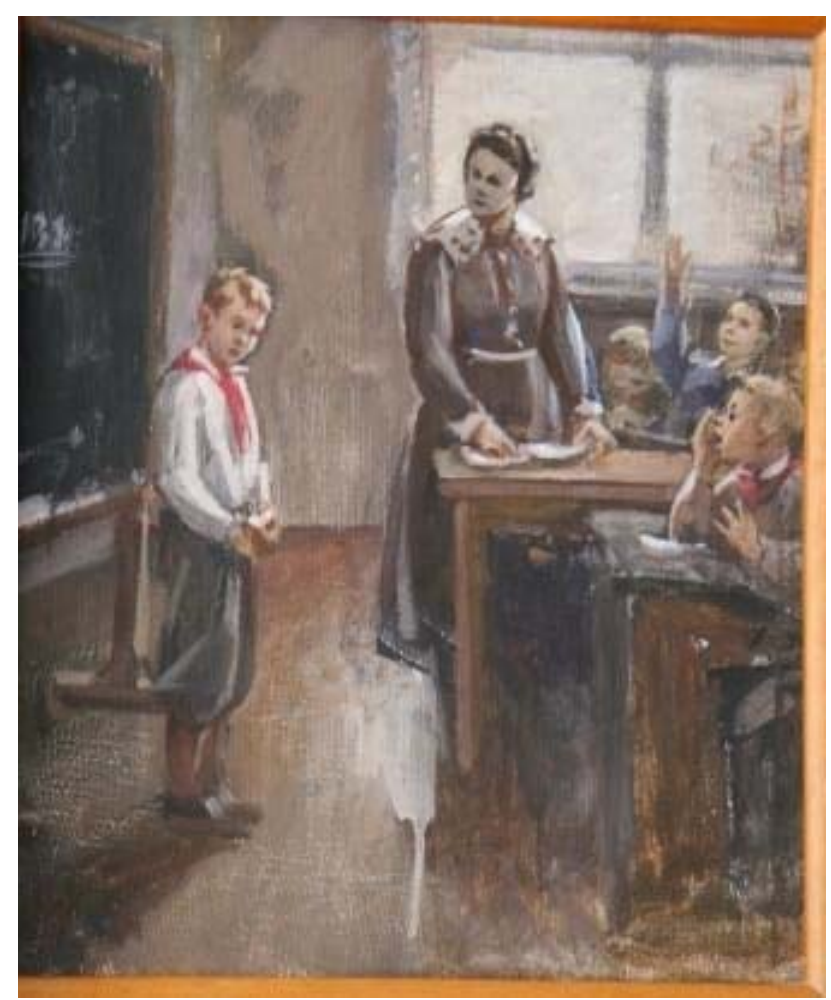

Figure 2. Fyodor Reshetnikov, Low Marks Again, early version.

The author's exploration of dozens of paintings throughout history, in which dogs are depicted, shows that no other work in which a dog in a painting expresses a human feeling (or, rather, moral), which is different from that of other depicted people, apparently may not be found.

\section{Russian Song That Conquered the World}

An international survey conducted in 1980 by the Moscow Radio revealed three Russian songs that people primarily associate with this category: Kalinka, Katyusha, and Moscow Nights. While the former two ones, being a military march by genre, are known mostly through their performance by the Red Army Song Ensemble, the latter song differs substantially, being one of the most soulful songs ever created in Soviet Russia.

The melody of the song was composed in 1955 by Vasily Solovyov-Sedoi. It was first named Leningrad Nights. The song was not performed, and even the composer himself did not expect it to be successful. But fate, however, decreed otherwise...

A year later, in 1956, the post-Stalin Soviet state perplexed everyone and everyone with the filming of sport movies. One such movie was a documentary film about athletics. In order not to finally put the spectator to sleep with sports propaganda, the directors decided to move away from the marching musical accompaniment typical of that time and turn their eyes on the lyrical songs. Then, Vasily Solovyov-Sedoy, known for his melodic talent, and the poet Mikhail Matusovsky were commissioned to write a song for the film. Here music from the "spare"

\footnotetext{
9 “Fyodor Reshetnikov's Painting 'Low Marks Again"” (in Russian). Radio Echo of Moscow (Series: "Collection of the Tretyakov Gallery”), retrieved May 27, 2019 from https://echo.msk.ru/programs/tretiakovka/45754/.
} 
drawer of the composer's table came in handy. And yet, since the film was about the 1956 Spartakiad of the Peoples of the USSR ${ }^{10}$, held in Moscow, the Leningrad nights turned into Moscow nights (Mikhailina, 2006).

The famous Soviet singer Mark Bernes, who was offered to perform the song, refused, not understanding the highly lyrical text that was not typical of that time:

Не слышны в саду даже шорохи,

Все здесь замерло до утра.

Если б знали вы, как мне дороги

Подмосковные вечера.

\author{
Gardens fast asleep till the morrow, \\ Not a rustle heard, not a sound... \\ I'm in love with you, Nights by Moscow, \\ Magic nights of the setting sun. ${ }^{11}$
}

Another singer, found by film directors, did not satisfy the authors in view of the operatic presentation of the song. Finally, the song was performed not by a professional singer, but by an actor of the Moscow Art Theater, Vladimir Troshin. The film went unnoticed. It included only a fragment of the song, which was held as a background for a lively conversation of athletes. In a word, nobody noticed the song.

The situation began to change when the staff of the USSR State Committee for Television and Radio Broadcasting decided to broadcast the full recording of the song on the radio. Hundreds of letters asking to repeat the song, where the "river moves and does not move", began to come to the address of the Committee. This was the beginning of the phenomenal popularity of the song in the Soviet Union, which also brought all-Union fame to its first performer. The first phrase of the song, played on the vibraphone, has been used as a time signal at the popular news radio station Mayak since $1964^{12}$.

The international debut of the song Moscow Nights took place at the closing ceremony of the 6th World Festival of Youth and Students held in 1957 in Moscow. The event was attended by about 34,000 young people from more than 130 countries $^{13}$. Since then, over the decades, the song has become the hallmark of the Soviet Union in the world.

The person who greatly contributed to the international popularity of the song was American pianist Van Cliburn, a pupil of the famous Russian-born pianist Rosina Lhévinne and first-prize winner at the inaugural International Tchaikovsky Competition in Moscow (1958). Van Cliburn performed his own and at the same time very Russian-style piano version of Moscow Nights at the final concert of the competition and at many other concerts in the USA and around the world (Mikhailina, 2006). Yet, Cliburn's contribution was greater than the promotion of a particular song, since awarding him the first prize at the Tchaikovsky Competition came at the very peak of the Cold War and served as the first sign of the warming of relations between the USSR and the USA. Another evidence of the attention to the Soviet song, introduced by the pianist to the American audience, was the success of its instrumental version performed by the British band Kenny Ball and His Jazzmen. The single, released in 1961 under the title Midnight in Moscow, held the first place in the American Easy Listening chart for three weeks (Whitburn, 2002, p. 28).

The song Moscow Nights also became popular in mainland China, where some people consider this song a folk Chinese song. The composer Gao Ping wrote a composition Two Soviet Love Songs for Vocalizing Pianist (2003) making the piano arrangement of Evenings in suburban Moscow (that is, Moscow Nights) and Katyusha. "The two Soviet tunes are something I grew up with", states the musician. "They are still extremely popular in

\footnotetext{
${ }^{10}$ That is, the (former) Soviet Union or, officially, Union of Soviet Socialist Republics.

11 English translation: Vladimir Reznikov.

12 Retrieved June 6, 2019 from https://music-facts.ru/song/Rarely_Known/Podmoskovnie_vechera/.

13 According to: "Moscow marks 50 years since youth festival", Editorial, Russia Today, July 28, 2007. Retrieved June 4, 2019 from http://www.russiatoday.ru/features/news/11587.
} 
China and often heard in karaoke houses"14. As if confirming this, the President of People's Republic of China (PRC), Hu Jintao, a man who was not used to showing emotions in public, sang Moscow Nights in 2010 at a public event with such sincerity that he deserved a comment on YouTube ${ }^{15}$.

Whatsoever, time puts everything in its place, and the song Moscow Nights, giving way to Kalinka (written in 1860) and Katyusha (written in 1938) in representation of the Russian spirit, remained nonetheless an unsurpassed representative of the Russian soul.

\section{Rediscovery of the Red Blinker}

Owners of Audi on the streets of Boston (MA) or Vancouver (BC) do not really think about how their cars look from the back in the eyes of visitors to these cities from, say, Europe. However, while the European eye is used to seeing an amber turn signal, flashing or, more recently, working as a sequencer, on the same cars, in the North American version, there are red rear turn signals, either separate or in combination with brake lights. Behind the difference in design versions lay certain events and stories - it cannot be otherwise. The following is a brief history of the rules for turn signals in the USA and around the world, as well as the brand that was the first to restore the traditional American design of the rear lights using the latest technology.

Until the 1960s, front turn signals worldwide emitted white light, while rear turn signals emitted red. The automotive industry in the USA implemented amber front-turn signals for most vehicles starting in the 1963 model year, though legally front turn signals might still emit white light until the 1968 model year, whereupon amber became the only allowed color for front turn signals. The rear turn signals in the USA and Canada until this day may be red or amber. In the rest of the world, they have to be amber. International proponents of amber rear turn signals say they are more easily perceptible as such. Indeed, US studies, beginning in the 1990s onwards, demonstrated improvements in the speed and accuracy of drivers' reaction to stop lamps when the turn signals were amber rather than red. Nonetheless, American regulators and other proponents of red rear turn signals have asserted there is no historically proven safety benefit to amber signals, though it has been recognized since the 1960s that amber turn signals are more quickly spotted than red ones (Hitzemeyer, Wilde, \& Ellenberger, 1977; Allen, 2009).

$\mathrm{Be}$ that as it may, the red rear turn signals are directly associated with the imagery of the American car. This feature did not go unnoticed by the German automotive industry, which since the beginning of the 21 st century, has been manufacturing cars for the North American market with red rear turn signals, which is more of a global tribute to local culture. However, in the era of light-emitting diode (LED) technology, when the brake lights emit a very strong light and when the third (central) brake light has become mandatory, the old pattern of the rear turn signal, blinking as one of the brake lights, represents, in the opinion of the author, one of the most informative solutions for rear lights ever. Since 2011, the author has been following the dynamics in this area, visiting the USA regularly and also spending the 2013-2014 academic year in Vancouver, BC. During this period, the design of the rear lights in German cars on North American roads crystallized towards the gradual restoration of the old American practice of combining turn signals and brake lights in one unit. Throughout this period, Audi seems to have been leading the way (see Figure 3).

\footnotetext{
${ }^{14}$ Cited in "Two Soviet Love Songs for Vocalizing Pianist (for piano)". SOUNZ, Center for New Zealand Music, retrieved June 6, 2019 from https://www.sounz.org.nz/works/19365.

15 “第一次覺得他是有感情的!” (For the first time, I feel that he has feelings!). Retrieved June 5, 2019 from https://www.youtube.com/watch?v=s5GWSkdSIAM.
} 


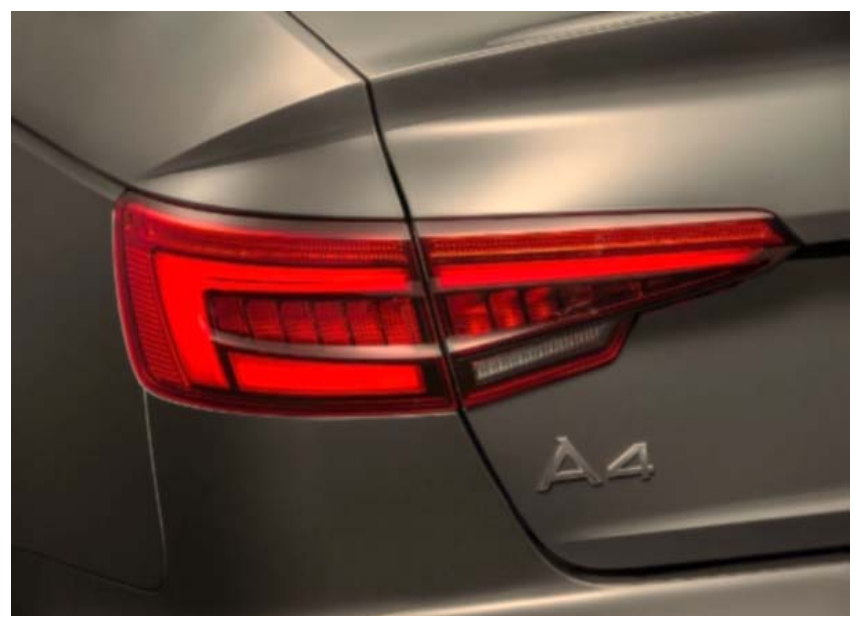

Figure 3. Audi A4 (2018), US stile left rear light.

The founder of the Audi brand, August Horch was one of two German engineers, each of whom is associated with two brands of automakers. The other was Ferdinand Porsche, who designed many cars, including the Mercedes-Benz SSK (1928) and the legendary Volkswagen Beetle (1938), which laid the foundation for the Volkswagen brand.

Born in 1868, August Horch first trained as blacksmith, then studied engineering. By 1896, just 11 years after Karl Benz patented his first car, he ran an engine workshop for Benz in Mannheim. Three years later, Horch, who already had his ideas for building cars, left Benz and opened his own company, August Horch \& Co, first in Ehrenfeld and then moved to Zwickau. From the very beginning, Horch understood the importance of motor racing in brand promotion and car sales (see Figure 4).

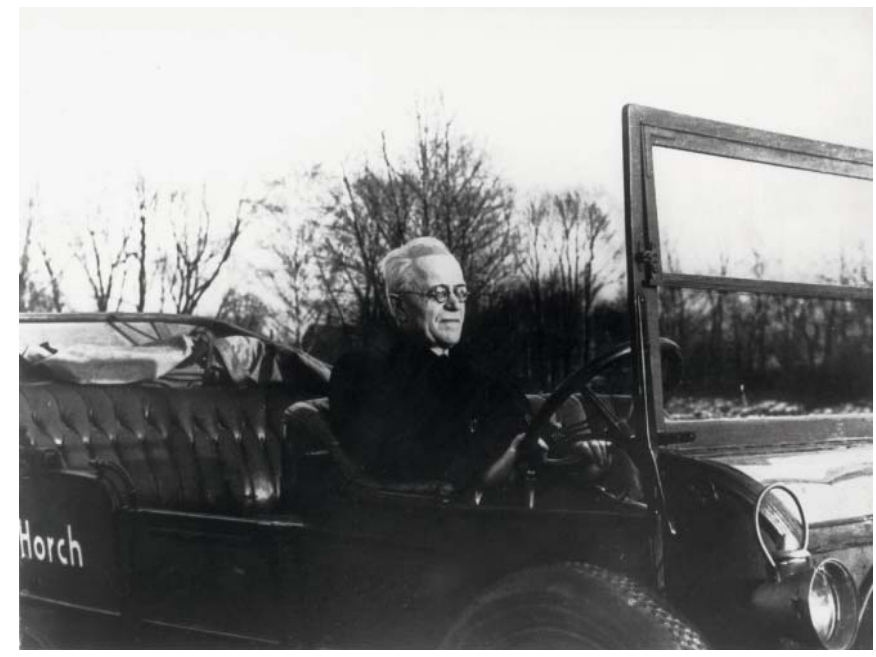

Figure 4. August Horch, driving the Horch car, c. 1908.

Among the reasons why Horch was forced to leave his firm after 10 years, some point to disagreements with the financial management of the company over the investments to racing performances of Horch cars (Ciano 2018). Then, in 1909, Horch founded in Zwickau his second company that also initially beard his name. However, after he was prohibited from using "Horch" as a trade name in his new car business, Kirchberg testifies, 
he called a meeting with close business friends, Paul and Franz Fikentscher from Zwickau. At the apartment of Franz Fikentscher, they discussed how to come up with a new name for the company. During this meeting, Franz's son was quietly studying Latin in a corner of the room. Several times he looked like he was on the verge of saying something but would just swallow his words and continue working, until he finally blurted out, "Father...wouldn't it be a good idea to call it audi instead of horch?" "Horch!" in German means "Hark!" or "hear", which is "Audi" in the singular imperative form of "audire"- "to listen"-in Latin. The idea was enthusiastically accepted by everyone attending the meeting. (Kirchberg, 1996, p. 30)

Horch left his second company in 1920 for a position in the German Ministry of Transportation, while he remained a member of Audi's trustees. In 1932, the two companies founded by Horch merged into Auto Union, which included two more companies. Four linked rings became the logo of the union. Ironically, after the World War II, the production of the infamous "people's car" Trabant (with two-stroke engine) was launched at the Zwickau (then GDR ${ }^{16}$ ) facilities of the former Audi company. The one who revived the brand and the ideas of its founder was Volkswagen AG, which itself began with the production of a "people's car" (namely, "Volkswagen" in German) created by Ferdinand Porsche.

"Any car that takes you from A to B does not take you far enough", Horch once said ${ }^{17}$. Throughout his life, August Horch "worked doggedly to follow his guiding principle— to build 'only large, powerful and good cars', no matter what" ${ }^{\prime 1}$. This is the principle of Audi AG to this day, introducing the latest developments and at the same time carefully restoring the "well forgotten old", such as the old American design of the tail lights.

\section{A Spanish-Lebanese Ballad}

The Spanish Civil War (1936-1939) did not leave artists in many countries indifferent. Hemingway's novel For Whom the Bell Tolls and Picasso's Guernica are only the most famous works related to the subject. Concierto de Aranjuez for guitar and orchestra (1939) by Spanish composer Joaquín Rodrigo is another such work that reflects the feelings of the artist who during the war stayed in Paris...

The concerto, as composer himself describes it, conveys "the fragrance of magnolias, the singing of birds, and the gushing of fountains" ${ }^{\prime 19}$ in the gardens of the Royal Palace of Aranjuez ${ }^{20}$. Rodrigo, who had lost his sight at the age of three, could not see the beauty of this place, but transmitted in sounds all images a blind man would appreciate. Yet, the beauty of the gardens hides the composer's pain about his country in the flames of civil war joined by personal experiences - devastation at the miscarriage of the first pregnancy of Rodrigo's wife Victoria (Rodrigo, 1992, p. 108). The circumstances accompanying the creation of the work were complicated by the difficult financial situation in which the composer's family found itself after the scholarship granted to the composer by the Spanish government for professional specialization in Paris was canceled due to the outbreak of civil war (Zinger, 1999). Fortunately, Concierto de Aranjuez, premiered in the homeland of the composer in 1940 and immediately evaluated everywhere, solved the material problems of the composer once and for all, since this work was recognized as one of the best in classical music of the 20th century and performed in both the original version and in countless transcriptions.

\footnotetext{
16 That is, East Germany or, officially, German Democratic Republic.

${ }^{17}$ Cited in Ciano 2018.

18 Personal details on August Horch at Audi Media Center, retrieved June 7, 2019 from https://www.audi-mediacenter.com/ en/personal-details-313.

${ }_{19}$ Many sources cite this description without reference to where it was originally published. The author retrieved it June 9, 2019 from: Concierto. "Composers-Joaquín Rodrigo", http://concierto.org/artists/composers/item/806-con-joaquin-rodrigo.

${ }^{20}$ This palace is the former Spanish royal residence located $50 \mathrm{~km}$ south of Madrid in the city of Aranjuez, built at the end of the 16 th century and rebuilt two centuries later into its present appearance.
} 
The second movement of the concerto is the dialogue between the guitar and solo woodwinds. It was this movement that attracted much attention from both performers and arrangers. Miles Davis, a famous jazz trumpeter who recorded his own (in collaboration with Gil Evans) version of this movement for his album Sketches of Spain (1960), noted: "That melody is so strong that the softer you play it, the stronger it gets, and the stronger you play it, the weaker it gets" (Shaw, 2008, p. 30).

Songs based on the music of the second movement of the concerto appeared in the late 1960s. Thus, Richard Anthony recorded in 1967 a single singing this melody with a French lyric written by Guy Bontempelli, which combines the love for Aranjuez's beauty with the memory of the war:
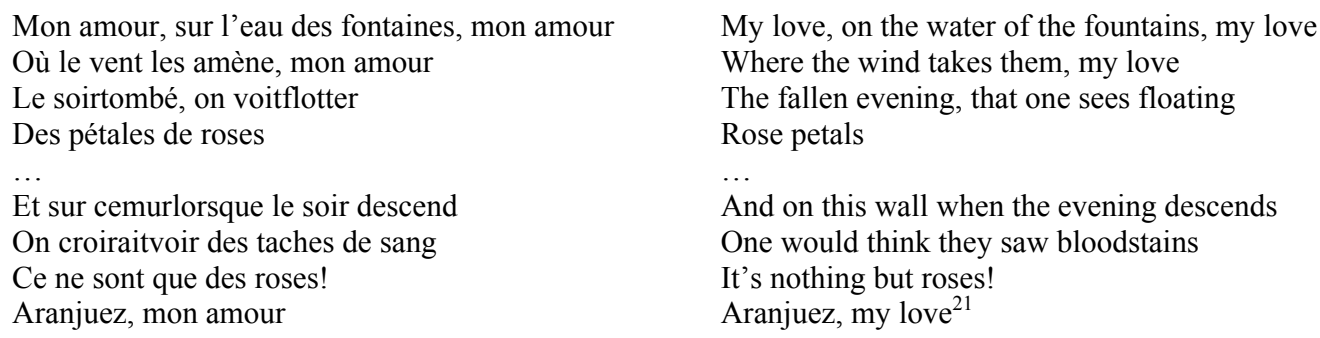

One year later, in 1968, the Greek singer Nana Mouskouri recorded a German version of this song under the title Aranjuez-Melodie (lyrics by Walter Brandin). In the following years, she performed the song in various languages, including original Bontempelli's French lyrics, which is perhaps the most famous of her performances of this song.

The English version of this song by Demis Roussos (Follow Me, 1982) is not related to the symbols of Aranjuez or war. This is a lyrical song of more common feelings, in which the singer calls (the beloved) to follow him across the sea. The Hebrew version of the song (Rainbow Song, 1988, lyrics by Yehonatan Geffen), performed by Israeli singer Rita, is written in a similar way. This version, however, takes the listener to the story of a man and a woman, which occurs against the backdrop of rain. Almost all versions of the song are created within the Mediterranean and are somehow connected with the imagery of the water (fountain, sea, or rain) which is part of the original imagery of Rodrigo's composition.

And yet, the version of the song that is closest to the original work is perhaps the song Li Beirut (1987, Arabic text by the Lebanese poet Joseph Harb), performed by the iconic Lebanese diva Fairuz. The singer's son, composer Ziad Rahbani, arranged the song, carefully following Rodrigo's score. The song was created in a situation very reminiscent of the one in which the original work was created: The Lebanese Civil War (1975-1990) was still ongoing, although its end was already on the horizon. The lyrics contain all the components of Rodrigo's original tangle of feelings: pain for a beloved city, personal experiences, and the beauty of nature:
To Beirut
I send a greeting... from my heart to Beirut,
I send kisses to the sea and to the houses,
to a rock that looks like and old sailor's face.
Beirut has been wine made from the soul of the people.
It has been bread and jasmines made from their sweat,
then why does it taste now like fire and smoke? ${ }^{22}$

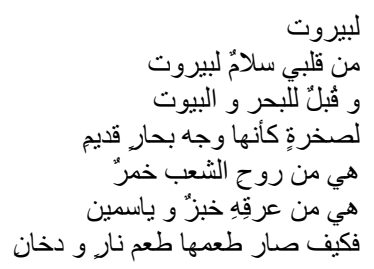

\footnotetext{
${ }^{21}$ English translation, retrieved June 9, 2019 from Lirics Translate. https://lyricstranslate.com/en/aranjuez-mon-amour-aranjuezmy-love.html.

${ }_{22}$ English translation, retrieved June 8, 2019 from Lirics Translate. https://lyricstranslate.com/en/li-beirut-beirut.html\#song translation.
} 
Thus, Fairuz, having invested her pain about her native city, that suffered the war, into the Western melody, created the bridge that connects people from different countries and cultures on the basis of common human feelings, where tragedy unites, rather than separates. Song Li Beirut was acknowledged not only in the Arab world, but in also in other countries, in particular, in Israel, where Rodrigo's melody is primarily associated with the Lebanese song and where, due to the multicultural makeup of the society, the interpenetration of Western and Eastern cultures became part of socio-cultural agenda and everyday practices.

\section{Conclusions}

The purpose of the article was to emphasize the importance of studying the socio-cultural context of works of art that have received significant (but not the highest) recognition on a global scale. Attention of the author to this niche of research is conditioned by his research philosophy, proposing that collecting "stories behind artifacts" provides the human and academic curiosity of an investigator with important details about the era and its customs, which at the end contributes to better understanding of the milieu for "top-tier" artworks about which we have otherwise only prejudgment obtained in the school.

The objects of main discussion were five local stories, each of which, it would seem, was not related to the other. Nevertheless, the common is that all these stories are about socio-cultural circumstances that led to the creation of artworks, which the author pre-defined as "the global artifacts of second echelon". The approach to each certain artwork, be it song, painting, or the design of rear turn signals, was developed on the basis of disciplinary affiliation, whereas a discipline was more sociology, anthropology, or history of an appropriate art, than its theory. Another research method placed local context in the test tube of globalization. Experience shows that these two methods are applicable to different arts, locations and periods, but first and foremost to modern and postmodern art.

The author expresses hope that, following the above methodology, the researchers of various sociology-based disciplines will jointly find the answers to the questions, such as: Why has Duchamp's urinal for a hundred years been a symbol of novelty in art? Why the painting by Claude Monet is today sold for the amount that possibly exceeds the gross income of a small country, whose folk art is no less interesting, expressive, and valuable in the eyes of an unbiased art lover?

\section{References}

Allen, K. (2009). The effectiveness of amber rear turn signals for reducing rear impacts. US Department of Transportation: National Highway Traffic Safety Administration.

Appadurai, A. (1996). Modernity at large: Cultural dimensions of globalization. Minneapolis: University of Minnesota Press.

Brauer, F. (2013). Rivals and conspirators: The Paris salons and the modern art centre. Newcastle upon Tyne: Cambridge Scholars Publishing.

Ciano, E. (2018). Why is Audi called Audi? Rewind \& Capture. Retrieved from https://www.rewindandcapture.com/why-isaudi-called-audi/

Hitzemeyer, E., Wilde, H., \& Ellenberger, D. (1977). What color should rear turn signals be? Society of Automotive Engineers (SAE) Technical Paper 770812. Retrieved from https://doi.org/10.4271/770812

Kirchberg, P. (1996). A history of progress: Chronicle of the Audi AG. Ingolstadt: Audi AG, Public Relations.

Konečni, V. J. (1984). Elusive effects of artists' "messages". In W. R. Crozier and A. J. Chapman (Eds.), Cognitive processes in the perception of art (pp. 71-96). Amsterdam: Elsevier Science Publishers.

Loomba, A. (1998). Colonialism/Postcolonialism. London: Routledge.

Mikhailina, Е. (2006). Что ж ты, милая, смотришь искоса... (What are you, my dear, looking askance...). Moskovskij Komsomolets, (2270), 12. 
Regev, M., \& Seroussi, E. (2004). Popular music and national culture in Israel. Berkeley: University of California Press.

Rodrigo, V. K. (1992). Hand in hand with Joaquin Rodrigo: My life at the Maestro's side. (E. Wilkerson, Trans.). Pittsburgh: Latin American Literary Review Press.

Shaw, R. (2008). Hand made, hand played: The art \& craft of contemporary guitar. New York: Sterling Publishing Company Inc. Stokes, M. (2004). Music and the global order. Annual Review of Anthropology, 33, 47-72.

Volkov, Y. (1967). Songs, opera, singers of Italy (in Russian). Moscow: Iskusstvo.

Whitburn, J. (2002). Billboard top adult contemporary: 1961-2001. Menomonee Falls: Record Research Inc.

Zinger, P. (1999). A composer who found strength in an inner vision. The New York Times, August 29, p. 23. 